\title{
Response of Two Chickpea (Cicer arietinum L.) Varieties to Rates of Blended Fertilizer and Row Spacing at Tselemti District, Northern Ethiopia
}

\author{
Tesfahun Mekuanint $\mathbb{D}^{1},{ }^{1}$ Yemane Tsehaye, ${ }^{2}$ and Yemane G. Egziabher ${ }^{2}$ \\ ${ }^{1}$ Shire-Maytsebri Agricultural Research Center, Shire-Endasilase, Tigray, Ethiopia \\ ${ }^{2}$ Mekelle University, Department of Dry Land Crop and Horticultural Sciences, Mekelle, Tigray, Ethiopia \\ Correspondence should be addressed to Tesfahun Mekuanint; tmekuanint@gmail.com
}

Received 2 April 2018; Accepted 4 September 2018; Published 4 October 2018

Academic Editor: Christos Tsadilas

Copyright ( $) 2018$ Tesfahun Mekuanint et al. This is an open access article distributed under the Creative Commons Attribution License, which permits unrestricted use, distribution, and reproduction in any medium, provided the original work is properly cited.

\begin{abstract}
Effects of row spacing, blended fertilizer rates, and varieties on some agronomic traits of chickpea were evaluated with the objective of investigating response of Kabuli and Desi type chick pea varieties to blended fertilizers rates and interrow spacing. The study was done using split plot design interrow spacing as a main plot, and fertilizer and variety as a subplot, where three row spacings $(20 \mathrm{~cm}, 30 \mathrm{~cm}$, and $40 \mathrm{~cm})$ were assigned to the main plot while the factorial combination of four blended (NPSB) fertilizer rates $(0 \mathrm{~kg} / \mathrm{ha}, 50 \mathrm{~kg} / \mathrm{ha}, 100 \mathrm{~kg} / \mathrm{ha}$, and $150 \mathrm{~kg} / \mathrm{ha})$ and representative of Kabuli and Desi type chickpea varieties such as Arerti and Mariye, respectively, were assigned to the subplot. Main effect of interrow spacing did not show significant difference on many studied agronomic parameters. Similarly, main effect of blended fertilizer rates and varieties did not reveal a significant difference for the studied parameters. However, significant differences were obtained on phenology, yield components, and yield for the varieties. Blended fertilizer rates utilized in Tselemti District did not show differences in most of studied traits. Reasonable row spacing of $20 \mathrm{~cm}$ for both types of chickpea could be used for the studied area.
\end{abstract}

\section{Introduction}

In Ethiopia, Chickpea is the third leading food legume in the area and its production is second to faba bean and haricot bean. It is an integral part of the cropping system of the farmers all over the country, because this crop fits well in the crop rotation and mixed cropping system. It has multiple uses and the ability to grow under the condition of low fertility and varying conditions of soil and climate [1].

The yield potential of present day chickpea cultivars exceeds $4.0 \mathrm{tha}^{-1}$ [2], while the average national yield is stagnating around $1.9 \mathrm{tha}^{-1}$ and the regional average yield is $1.4 \mathrm{tha}^{-1}$ [3]. The gap between average yield and potential yield is mostly due to poor crop management and cultural practices such as imbalanced use of fertilizer, lack of improved varieties to different environmental condition, and inappropriate use of plant density. In the study area, Agricultural Transformation Agency recommended site specific blended fertilizer but relatively no investigations have analyzed the application rates of the new recommended site specific nutrient blended fertilizer NPSB $\left(18.1 \mathrm{~N}, 36.1 \mathrm{P}_{2} \mathrm{O}_{5}\right.$, $6.7 \mathrm{~S}$, and $0.71 \mathrm{~B}$ or $95 \mathrm{~kg} / 100 \mathrm{~kg}$ NPS $+4.9 \mathrm{~kg}$ Borax) on chickpea and agronomic managements for improving crop productivity. Besides, in the study area limited research has been done on the interaction effects of various agronomic practices such as variety spacing and its effect in different chickpea varieties such as Kabuli and Desi type. These are two distinct types of chickpea, called Desi and Kabuli, that differ in size, color, and surface of seeds, flower color, and morphology. Both these types are divergent geographically and broadly vary in their adaptation, nutrition, and biotic and abiotic stress tolerance [4].

Optimum plant population of a crop at one location may not be applied at other locations because of variation infertility status of the soil, rainfall distribution, and nutrient and moisture availability. There is also no site and variety 


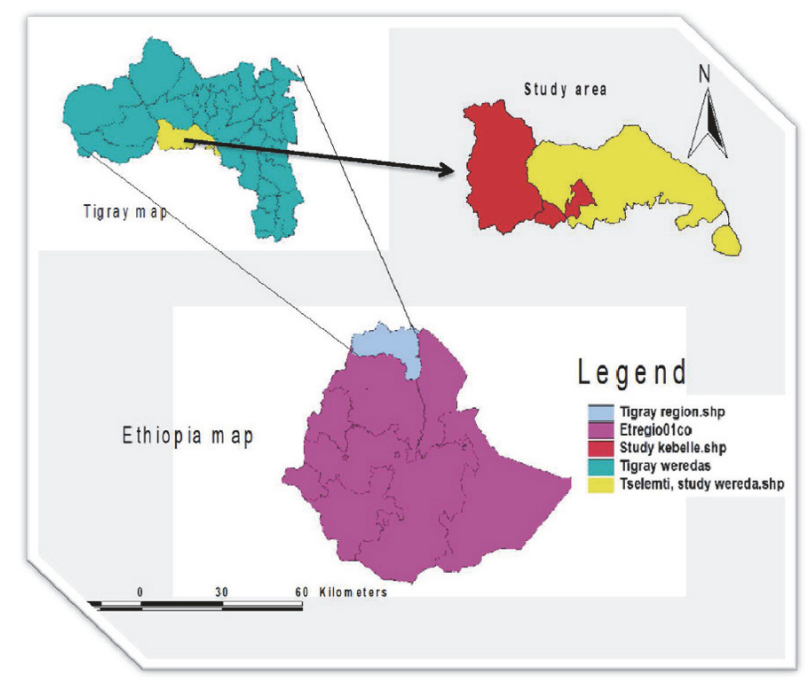

FIGURE 1: Location of the study area.

specific recommendation on the plant population of chickpea variety in Ethiopia; rather there is blanket recommendation of spacing of $30 \mathrm{~cm} \times 10 \mathrm{~cm}$; this is irrespective of factors such as the maturity group, growth habit, and soil condition and vegetation zone varieties of Kabuli and Desi type and agroclimatic condition. There are few research and information about growth and development response of chickpea cultivars to change in plant population. Hence, both types of chickpea are produced in the country as well as in the study area (Figure 1); it requires developing site specific row spacing recommendations for chickpea varieties through conducting experiments for the area. Selection of best variety accompanied with appropriate fertilizer rate and optimum plant density is very important to enhance the productivity of chickpea varieties. Therefore, this study was initiated to identify appropriate rates of blended fertilizer and row spacing for varieties of chickpea in the study area.

\section{Materials and Methods}

Two chickpea varieties, Mariye (Desi type) and Arerti (Kabuli type), released by Debre Zeit Agricultural research center were used for the study. The field experiment was laid out as a split plot design spacing as a main plot fertilizer and variety as a subplot. The interrow spacings of $20 \mathrm{~cm}$ (500,000 plants), $30 \mathrm{~cm}\left(333,333\right.$ plants ha $\left.{ }^{-1}\right)$, and $40 \mathrm{~cm}\left(250,000\right.$ plants ha $\left.{ }^{-1}\right)$ were assigned to the main plot whereas varieties Arerti (Kabuli type) and Mariye (Desi type) and blended fertilizer (NPSB 18.1\% N, 36.1\% $\mathrm{P}_{2} \mathrm{O}_{5}, 6.7 \% \mathrm{~S}$ and $0.71 \% \mathrm{~B}$ ) with four levels $\left(0 \mathrm{~kg} \mathrm{ha}^{-1}, 50 \mathrm{~kg} \mathrm{ha}^{-1}, 100 \mathrm{~kg} \mathrm{ha}^{-1}\right.$, and $\left.150 \mathrm{~kg} \mathrm{ha}^{-1}\right)$ was assigned to the subplot with twenty-four treatment combinations replicated three times. The fertilizer rates were applied by dibbling during sowing of the experiment. The experiment was planted in September, 2016 (Figure 2).

Surface soil samples $(0-30 \mathrm{~cm})$ were collected before sowing and after harvesting from 72 spots and composited and analyzed in the laboratory for selected chemical and
TABLE 1: Chemical and physical characteristics of the soil of experimental site.

\begin{tabular}{lc}
\hline Parameters & Value \\
\hline Sand (\%) & 14 \\
Clay (\%) & 22 \\
Silt (\%) & 64 \\
Av.K(ppm) & 27.5 \\
Av.Pppm & 2.844 \\
TN (\%) & 0.078 \\
EC(us) & 518 \\
EC(mmh) & 0.518 \\
OM (\%) & 1.559 \\
CEC $\left(\mathrm{meq}^{-100}\right.$ g soil) & 68 \\
EC $\left(\mathrm{dSm}{ }^{-1}\right)$ & 0.32 \\
pH & 6 \\
\hline
\end{tabular}

(2016, Shire soil research center).

physical soil properties (Table 1). Soil texture determination was done by hydrometric method [5]. Organic matter was determined based on the oxidation of organic carbon with acid dichromate medium following the Walkley and Black method as described by Dewis and Freitas [6]. Kjeldahl method [6] was used to determine total N. The available soil P was determined according to the methods of Olsen and Dean (1965), available K using the Morgan method [7] CEC using Ammonium Acetate method Okalebo et al. [8], and EC using EC Meter [9]. Soil pH was determined in $1: 2.5$ soils : water ratio using a glass electrode attached to a digital $\mathrm{pH}$ meter [9].

The size of each main plot was $17.9 \mathrm{mx} 4 \mathrm{~m}\left(71.6 \mathrm{~m}^{2}\right)$ and the size of each subplot was $1.8 \mathrm{~m} \times 4 \mathrm{~m}\left(7.2 \mathrm{~m}^{2}\right)$. The spacing between main plots, subplots, blocks, and plants was $1 \mathrm{~m}, 0.5 \mathrm{~m}, 1 \mathrm{~m}, 2 \mathrm{~m}$, and $0.1 \mathrm{~m}$, respectively. Total area of the experiment was $55.7 \mathrm{mx16m}\left(891.2 \mathrm{~m}^{2}\right)$. Seeds were sown in an interrow spacing of $20 \mathrm{~cm}, 30 \mathrm{~cm}$, and $40 \mathrm{~cm}$ and $10 \mathrm{~cm}$ 
TABLE 2: Chickpea phenological and growth parameters as influenced by main effect of interrow spacing, variety, and interaction effect of blended fertilizer rates $(\mathrm{kg} / \mathrm{ha})$ and varieties.

\begin{tabular}{|c|c|c|c|c|c|c|}
\hline Treatments & $\mathrm{DE}$ & DF & $\mathrm{DM}$ & NSBPP & NPMBPP & PLHT(c.m) \\
\hline \multicolumn{7}{|l|}{ Row spacing } \\
\hline $20 \mathrm{c} . \mathrm{m}$ & 9.54 & 68.1 & 118.6 & 5.75 & 3.50 & 41.33 \\
\hline $30 \mathrm{c} . \mathrm{m}$ & 9.62 & 68.7 & 118.2 & 6.36 & 2.83 & 40.50 \\
\hline 40c.m & 9.83 & 69.7 & 118.4 & 6.91 & 3.21 & 41.00 \\
\hline $\operatorname{LSD}(0.05)$ & ns & ns & ns & ns & ns & ns \\
\hline CV (\%) & 9.1 & 6.3 & 3.4 & 21.1 & 25 & 4.7 \\
\hline \multicolumn{7}{|l|}{ Varieties } \\
\hline Mariye & 10.22 & 61.83 & 107.14 & 5.63 & 2.72 & 40.72 \\
\hline Arerti & 9.11 & 75.89 & 129.67 & 7.06 & 3.64 & 41.17 \\
\hline $\operatorname{LSD}(0.05)$ & $0.418^{* *}$ & $2.63^{* *}$ & $1.926^{* *}$ & $0.68^{* *}$ & $0.49^{* *}$ & $\mathrm{~ns}$ \\
\hline \multicolumn{7}{|l|}{$\mathrm{F}$ and $\mathrm{V}$} \\
\hline $0, \mathrm{~V} 1$ & 10.4 & 62.11 & 107.44 & 6.07 & 2.44 & 40.44 \\
\hline $50, \mathrm{~V} 1$ & 10.2 & 60.44 & 107.11 & 5.58 & 2.56 & 40.44 \\
\hline $100, \mathrm{~V} 1$ & 9.89 & 62.67 & 107.67 & 5.58 & 2.89 & 40.44 \\
\hline $150, \mathrm{~V} 1$ & 10.3 & 62.11 & 106.33 & 5.31 & 3.00 & 41.56 \\
\hline $0, \mathrm{~V} 2$ & 9.44 & 75.44 & 131.00 & 7.29 & 3.33 & 41.11 \\
\hline $50, \mathrm{~V} 2$ & 8.78 & 77.67 & 128.44 & 6.88 & 3.89 & 41.11 \\
\hline $100, \mathrm{~V} 2$ & 9.22 & 75.56 & 130.11 & 7.11 & 3.56 & 40.11 \\
\hline $150, \mathrm{~V} 2$ & 9.00 & 74.89 & 129.11 & 6.96 & 3.78 & 42.33 \\
\hline $\operatorname{LSD}(0.05)$ & $\mathrm{ns}$ & ns & ns & ns & ns & $\mathrm{ns}$ \\
\hline
\end{tabular}

DF: days to 50\% flowering; DM: days to 90\% maturity; NPMBPP: number of primary branch per plant; NSBP: number of secondary branches per plant; PLHT: plant height; CV: coefficient of variation; LSD: least significant difference; V1: Mariye (D); V2: Arerti (K); F: fertilizer; V: variety.

between plants to all experimental plots uniformly. The seeds were sown by placing two seeds per hole at a specific interrow spacing and intrarow spacing. Plots with $20 \mathrm{~cm}, 30 \mathrm{~cm}$, and $40 \mathrm{~cm}$ interrow spacing consisted of 9 rows, 6 rows, and 4 rows, respectively.

The net plot size for row spacings $20 \mathrm{~cm}, 30 \mathrm{~cm}$, and $40 \mathrm{~cm}$ was $5.6 \mathrm{~m}^{2}, 4.8 \mathrm{~m}^{2}$, and $3.2 \mathrm{~m}^{2}$, respectively. They were used for data collection and measurements. Thinning was done to maintain an appropriate population ten days after planting. Any other important agronomic practices like weeding were carried out uniformly for all the experimental units throughout the cropping season.

2.1. Data Analysis. The various agronomic data collected were subjected to analysis of variance (ANOVA) following an appropriate procedure to split plot design using the Genstat statistical software. Whenever the effects of the factors and interactions were found to be significant, the means were compared using the least significant differences (LSD) test at $5 \%$ level of significance.

\section{Result}

3.1. Days to $50 \%$ Emergence. The main effects of variety showed a highly significant effect $(\mathrm{P}<0.01)$ on days to $50 \%$ emergence indicating that varieties behaved differently for days to $50 \%$ emergence (Table 2). The Desi type Mariye emerged after 9.11 days on average while the Kabuli type chickpea variety Arerti emerged after 10.2 days and the variety

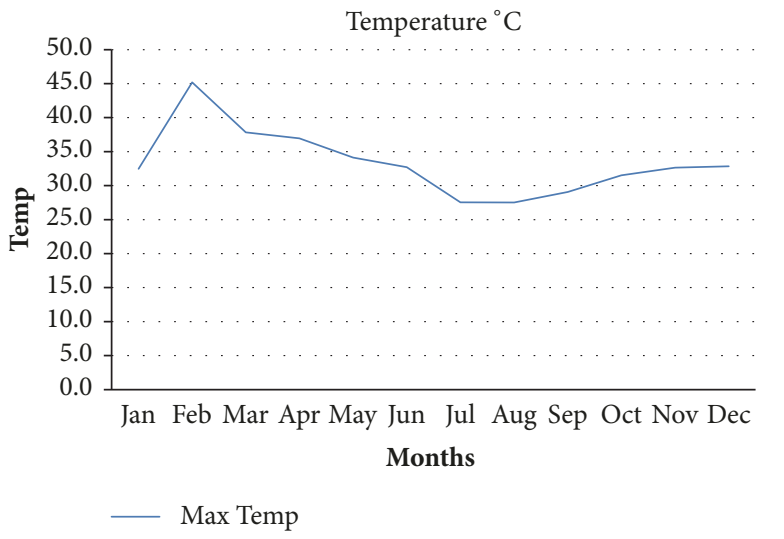

FIGURE 2: Maximum temperature during the cropping season (2016, Tigray Regional Meteorological Agency).

average values were statistically different from each other $(\mathrm{P}<0.01)$. Nevertheless, there was no significant difference among row spacing and fertilizer rates as well as all the interaction components on days to $50 \%$ emergence (Table 2).

3.2. Days to $50 \%$ Flowering. Main effect of row spacing and different levels of blended fertilizer rates did not show significant variation for days to $50 \%$ flowering but highly significant effect $(\mathrm{P}<0.01)$ was observed between varieties on days to flowering (Table 2). The Desi type chickpea (Mariye) and the Kabuli type (Arerti) variety reached flowering on 61 
and 75 days on average, respectively. However, all interaction effects were not statistically different from each other.

3.3. Days to Maturity. Highly significant differences $(\mathrm{P}<0.01)$ between varieties were recorded for number of days to $90 \%$ physiological maturity (Table 2). The number of days taken to reach $90 \%$ physiological maturity for varieties, Mariye and Arerti, were 107 and 129 days, respectively. Kabuli type Arerti matures significantly latter than Mariye, despite the fact that no statistical difference was observed by the main effect of row spacing. Besides, interaction effects of variety and blended fertilizer application rates did not significantly influence days to physiological maturity (Table 2).

3.4. Plant Height. The result showed no significant difference for plant height between the Desi and Kabuli varieties in response to different blended fertilizer rates (Table 2). Plant height was not affected significantly by the main effects of interrow spacing. The nonsignificant effect of row spacing on mean plant height observed in this study might be attributed to the fact that crop density has often, but not always, been associated with increased plant height. The interaction effects also did not influence significantly the mean plant height of chickpea varieties (Table 2).

\subsection{Growth Parameters}

3.5.1. Number of Primary Branches. Branching is basically a genetic character and plays an important role in enhancing seed yield. The variety main effects show a highly significant $(\mathrm{P}<0.01)$ variation for number of primary branches per plant. Apparently, variety Mariye had the fewer number of primary branch per plant (2.78) while variety Arerti had higher number of primary branches per plant (3.57) (Table 3). Nevertheless, the interrow spacing main effect and interaction of fertilizer rate and varieties effects depicted a statistically nonsignificant variation (Table 3).

3.5.2. Number of Secondary Branches. The number of secondary branches determines the sum number of leaves, and hence the total photosynthetic area. The analysis of variance revealed a highly $(\mathrm{P}<0.01)$ significant variation for the variety main effect for secondary branches. Maximum secondary branches (7.06) were recorded from Arerti (Kabuli type) while the minimum (5.6) secondary branches were obtained from Mariye (Desi type). However, the interrow spacing main effect and interaction of blended fertilizer rates and varieties did not show a significant difference (Table 3 ).

\subsection{Yield and Yield Components}

3.6.1. Number of Pods per Plant. The analysis of variance revealed (Table 3 ) a nonsignificant effect of interrow spacing and varieties main effect for number of per pods per plant. Regarding the effect of blended fertilizer rates and variety, the analysis of variance does not show a significant difference for number of pods per plant.
(1) Number of Seeds per Pod. Data regarding number of seeds per pod given in Table 3 revealed that varieties had a significant variation $(\mathrm{P}<0.05)$ for the number of seeds per pod. The highest average number of seeds per pod (2) was produced by Mariye and the lowest (1) a seed per pod was produced by Arerti. However, the analysis of variance showed that the effects of varieties and fertilizer rates did not show a significant effect on the number of seeds per pod. In addition, main effect of interrow spacing did not show a significant difference for number of seeds per pod (Table 3 ).

3.7. Biomass Yield. The analysis of variance revealed a nonsignificant effect of interrow spacing main effect on biomass production (Table 4). In addition, biomass yield did not vary among chickpea varieties (Table 4). Regarding effect interaction of blended fertilizer rates and varieties, the analysis of variance did not show a significant difference on biomass production.

3.8. Grain Yield. Data pertaining to the seed yield (Table 4) elucidate a significant difference $(\mathrm{P}<0.01)$ between varieties. Higher seed yield $(1934 \mathrm{~kg} / \mathrm{ha})$ was obtained from Mariye while lower seed yield $(1719 \mathrm{~kg} / \mathrm{ha})$ was recorded from the variety Arerti (Table 4). Despite that the row spacing main effect did not show any statistical difference for grain yield. In addition, interaction effect of variety and blended fertilizer rates did not show a statistical difference.

3.9. Hundred-Seed Weight. Among the various parameters contributing towards final yield of a crop, hundred-seed weight is of prime importance. The analysis of variance revealed a highly significance difference $(\mathrm{P}<0.01)$ between varieties for hundred-seed weight. Maximum hundred-seed weight was obtained from the Arerti (25 g) and the minimum (22 g) was recorded from Mariye. But, the interrow spacing, different blended fertilizer rates, and varieties did not reveal a significant difference for this trait (Table 4).

3.10. Straw Yield. The output of analysis of variance in Table 4 revealed that the main effect of varieties showed a highly significant difference $(\mathrm{P}<0.01)$ on straw yield. Higher straw yield was recorded from the variety of Kabuli type of Arerti $(1684 \mathrm{~kg} / \mathrm{ha})$ whereas lower straw yield was recorded from the Desi type variety Mariye ( $1418 \mathrm{~kg} / \mathrm{ha}$ ) (Table 4$)$. The main effect of row spacing and interaction effect of fertilizer rates and varieties did not show a significant effect.

3.11. Harvest Index. Output of the analysis of variance revealed in (Table 4 ) that the variety main effect had a highly significant variation $(\mathrm{P}<0.01)$ for harvest index. The higher harvest index was recorded by Mariye (54) while the lower was by Arerti (48). In addition, main effect of interrow spacing showed a highly significant difference $(\mathrm{P}<0.01)$ for harvest index. Maximum harvest index (53.25) was recorded from interrow spacing of $40 \mathrm{~cm}$ (53.25) while minimum (49.37) was recorded from $20 \mathrm{~cm}$ interrow spacing. Regarding the interaction effect of variety and blended fertilizer rates, they were not found significant for harvest index. 
TABLE 3: Number of pods per plant and number of seeds per pod as influenced by main effect of interrow spacing, variety, interaction effect of blended fertilizer rates ( $\mathrm{kg} / \mathrm{ha})$, and varieties.

\begin{tabular}{|c|c|c|}
\hline Treatments & NPPP & NSPP \\
\hline \multicolumn{3}{|c|}{ Inter row spacing (c.m) } \\
\hline $20 \mathrm{c} . \mathrm{m}$ & 37.00 & 5.76 \\
\hline $30 \mathrm{c} . \mathrm{m}$ & 38.83 & 6.36 \\
\hline $40 \mathrm{c} . \mathrm{m}$ & 44.92 & 6.92 \\
\hline $\operatorname{LSD}(0.05)$ & ns & ns \\
\hline CV (\%) & 20 & 21.1 \\
\hline \multicolumn{3}{|l|}{ Varieties } \\
\hline Mariye & 41.78 & 5.63 \\
\hline Arerti & 38.72 & 7.06 \\
\hline $\operatorname{LSD}(0.05)$ & $\mathrm{ns}$ & $* *$ \\
\hline \multicolumn{3}{|l|}{$\mathrm{F}$ and $\mathrm{V}$} \\
\hline $0, \mathrm{~V} 1$ & 41.00 & 1.556 \\
\hline $50, \mathrm{~V} 1$ & 39.89 & 1.889 \\
\hline $100, \mathrm{~V} 1$ & 41.67 & 1.444 \\
\hline $150, \mathrm{~V} 1$ & 44.56 & 1.667 \\
\hline $0, \mathrm{~V} 2$ & 34.78 & 1.111 \\
\hline $50, \mathrm{~V} 2$ & 39.44 & 1.000 \\
\hline $100, \mathrm{~V} 2$ & 37.78 & 1.111 \\
\hline $150, \mathrm{~V} 2$ & 42.89 & 1.000 \\
\hline $\operatorname{LSD}(0.05)$ & ns & ns \\
\hline
\end{tabular}

** means highly significant; * means significant; ns: nonsignificant, NPPP: number of pods per plant, NSPP: number of seeds per pod, CV: coefficient of variation, LSD: least significant difference; V1: Mariye; V2: Arerti; F: fertilizer, and V: variety.

TABLE 4: Chickpea biomass yield, grain yield, straw yield, hundred-seed weight, and harvest index as influenced by main effect of interrow spacing, variety, and interaction effect of blended fertilizer rates and varieties.

\begin{tabular}{|c|c|c|c|c|c|}
\hline Treatments & $\begin{array}{c}\text { BY } \\
(\mathrm{Kg} / \mathrm{ha})\end{array}$ & $\begin{array}{c}\text { GY } \\
(\mathrm{Kg} / \mathrm{ha})\end{array}$ & $\begin{array}{c}\text { SY } \\
(\mathrm{Kg} / \mathrm{ha})\end{array}$ & $\begin{array}{l}\text { HSW } \\
\text { (g/ha) }\end{array}$ & $\begin{array}{l}\mathrm{HI} \\
(\%)\end{array}$ \\
\hline \multicolumn{6}{|c|}{ Inter row spacing (c.m) } \\
\hline 20c.m & 3496 & 1970 & 1629 & 24.08 & 49.37 \\
\hline $30 \mathrm{c} . \mathrm{m}$ & 3306 & 1713 & 1524 & 24.08 & 51.17 \\
\hline 40c.m & 3373 & 1796 & 1500 & 23.42 & 53.25 \\
\hline $\operatorname{LSD}(0.05)$ & ns & ns & ns & ns & $1.6^{* *}$ \\
\hline CV (\%) & 14 & 7.6 & 10.7 & 4.5 & 14.5 \\
\hline \multicolumn{6}{|l|}{ Varieties } \\
\hline Mariye & 3450 & 1934 & 1418 & 22.78 & 54 \\
\hline Arerti & 3333 & 1719 & 1684 & 24.94 & 48 \\
\hline $\operatorname{LSD}(0.05)$ & ns & $11.5^{* *}$ & $117.1^{* *}$ & $0.516^{* *}$ & $3.5^{* *}$ \\
\hline \multicolumn{6}{|l|}{$\mathrm{F}$ and $\mathrm{V}$} \\
\hline $0, \mathrm{~V} 1$ & 3348 & 1882 & 1342 & 22.44 & 54 \\
\hline $50, \mathrm{~V} 1$ & 3194 & 1795 & 1398 & 22.56 & 56 \\
\hline $100, \mathrm{~V} 1$ & 3661 & 2037 & 1496 & 23.11 & 54 \\
\hline $150, \mathrm{~V} 1$ & 3599 & 2022 & 1436 & 23.00 & 54 \\
\hline $0, \mathrm{~V} 2$ & 3358 & 1698 & 1714 & 25.44 & 51 \\
\hline $50, \mathrm{~V} 2$ & 3258 & 1675 & 1687 & 24.67 & 47 \\
\hline $100, \mathrm{~V} 2$ & 3383 & 1647 & 1603 & 24.56 & 45 \\
\hline $150, \mathrm{~V} 2$ & 3332 & 1855 & 1733 & 25.11 & 51 \\
\hline $\operatorname{LSD}(0.05)$ & $\mathrm{ns}$ & $\mathrm{ns}$ & $\mathrm{ns}$ & $\mathrm{ns}$ & ns \\
\hline
\end{tabular}

BY: biomass yield; GY: grain yield; SY: straw yield; HI: harvest index; HSW: hundred-seed weight; CV: coefficient of variation; V1: Mariye (D), V2: Arerti (K); F: fertilizer; V: variety. 


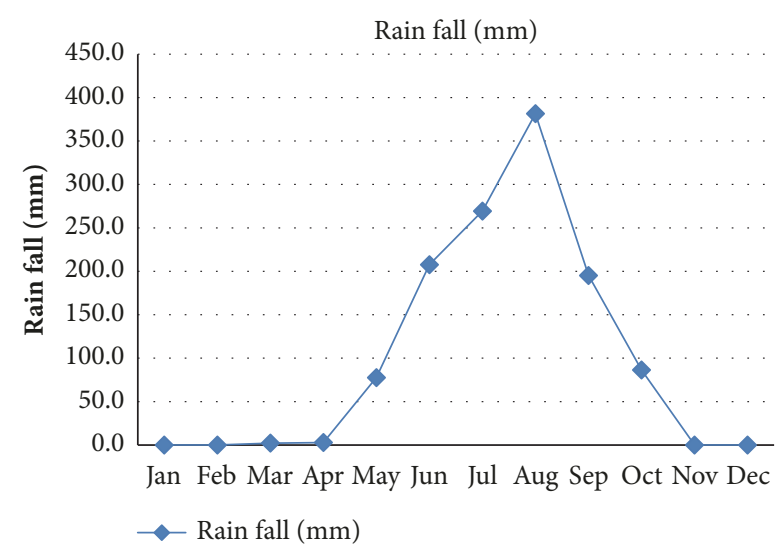

FIgURE 3: Rainfall during the cropping season (2016, Tigray Regional Meteorological Agency).

\section{Discussion}

Evaluation of chickpea, both Kabuli and Desi types, that has been undertaken in the present study revealed significant differences among the varieties. Main effect variety had a significant effect on the phenology, growth, yield components, and yield of chickpea. The variety with a long delay in flowering time was associated with a larger decrease in seed yield especially in moisture stress areas. Therefore, longer delay in flowering time may be an indication of the variety susceptibility to drought, and this character may be also used as an integrative trait to identify which type of chickpea is tolerant and susceptible to drought. It might be attributed to the fact that flowering time in chickpea is considered to be varietal characteristics, which is genetically controlled.

Previous studies showed that the differential response to flowering among varieties was distinct. For instance, Tripathi et al. (2013) reported differences among varieties of chickpea in days to $50 \%$ flowering. Similarly the two varieties tend to vary in their physiological maturity. The number of days taken to reach $90 \%$ physiological maturity for Mariye and Arerti was 107 and 129 days, respectively. This result indicated that the variety Kabuli type Arerti chickpea was matures significantly latter than Desi type Mariye.

Therefore, Kabuli type chickpea varieties could require long rainfall or moisture than Desi type chickpea varieties (Figure 3). Under worst climate scenario, where postflowering moisture stress is encountered, the Kabuli variety (Arerti) may not fit the study area. This finding agreed with report by Tripathi et al. (2013). Branching is basically a genetic character and plays an important role in enhancing seed yield. Apparently, variety Mariye had the lowest of number primary branches per plant while variety Arerti had highest number of primary branches per plant. This result was in line with the report of Addisu [10]. Varietal characteristics might have accounted for these significant differences observed in the branches, as they were grown under similar environment. But the main effect of interrow spacing did not show a significant effect on primary branch. This result is in agreement with the findings of Malek et al. [11].
Environmental factors and genetic characteristics of plants play an important role in determining the plant height. It is one of the desirable characters in a chickpea variety development. The Desi variety was in fact not genetically shorter than Kabuli variety. The result showed no significant difference for plant height between the Desi and Kabuli varieties in response to different blended fertilizer rates. This implies that the varieties responded in a similar manner to the recommended site specific fertilizer rates. This result is in line with the finding of Addisu [10] who reported nonsignificant effects of fertilizer treatment on a plant height in chickpea. Plant height was not also affected significantly by the main effects of interrow spacing. This result agrees with the finding of Uzun et al. [12]. The nonsignificant effect of row spacing on mean plant height observed in this study might be attributed to the fact that crop density has often, but not always, been associated with increased plant height. The interaction effects also did not influence significantly the mean height of chickpea varieties. This result was in agreement with the finding of Rasul et al. [13]. Number of pods per plant is a key factor for determining the yield performance in leguminous plants as indicated by Rasul et al. [13]. Plant growth behavior of legume crops including chickpea can be determined by number of pods per plant. The analysis of variance revealed a nonsignificant effect of interrow spacing main effect for number of seeds per pod. The result is in agreement with the finding of Farjam et al. [14] and Pooniya et al. [15]. In addition the interaction of variety and interrow spacing did show a significant effect. The result agrees with the report of Malek et al. [11]. Number of seeds per pod is considered to be an important factor that directly imparts potential yield in leguminous crops. Varieties effect on the number of seed per pod had a significant effect; maximum seeds per pod were produced by Mariye whereas the minimum seeds were obtained by the Kabuli type of variety Arerti. This result might be obtained due to seed size of the desi type of chickpea compared to the kabuli type.

Increase in dry matter accumulation is one of the criterions of crop growth. The result did not show a significant effect of interrow spacing for biomass production. This result agrees with the report of Mahmood and Honermeier [16] and Sarkodie-Addo and Mahama [17]. Biomass yield did not vary among chickpea varieties. This shows that the varieties studied might had equal growth and dry matter production potential. Dry matter production shown by varieties of the same crop under similar growth conditions is pinpointing of similar growth potential.

It is well known that seeds yield the result of several physiological and biochemical processes in the crop growth and development stages. In other words, yield depends, directly or indirectly, on the performances of other related traits. Therefore, reductions in the performances of other traits result in decrease in seed yield. The results from this investigation exhibited substantial differences among varieties for seed yield. Maximum seed yield was obtained from Mariye while the lowest seed yield was recorded from the variety Arerti. It might be due to genetic differences among the varieties. Under farming conditions, crop growth is dependent on the ability of the canopy to intercept incoming radiation. Despite 
the fact that the interrow spacing main effect did not show a statistical difference for grain yield, maximum grain yield was recorded from the narrow spacing and this was maybe due to the better soil (limited evapotranspiration) and leaf water status that leads to increase yield. This result is similar to report of Zhou et al. [18].

Moreover, efficient use of water results in reducing loss of soil water from evaporation due to quick canopy cover. Hence, the yield effects of row spacing are primarily related to efficient water use so the yield reductions from wider row spacing appear to be more pronounced. This result was concurrent to report of Raymond et al. [19] and Pooniya et al. [15].

Among various parameters contributing towards final yield of a crop, hundred-seed weight is of prime importance. A highly significant variation was observed between varieties for hundred-seed weight. Seed size is one of the most important yield related traits in chickpea crop and determines the final seed weight. The recorded variations for 100 seed weight could be attributed to small seed size. However, the main effect of interrow spacing on hundred seed weight was not found significant. A similar result of a nonsignificant effect of interrow spacing on hundred-seed was also reported Almaz et al. [20]

Main effect of varieties showed a highly significant difference on straw yield. Desi type of Mariye variety had better straw yield as compared to the Kabuli type of Arerti variety. This result is concurrent with the report of Pooniya et al. [15]. As chickpea straw is the main by-product produced after chickpea grain threshing and widely used as a ruminant feed (it contains higher nutritive value than cereal straw), selection for such a trait and enhancing straw yield may be effective in chickpea breeding. The interrow spacing main effect depicted a significant effect, harvest index appeared to increase as the interrow spacing increases from $20 \mathrm{~cm}$ to $40 \mathrm{~cm}$ and similar results were also reported by Almaz et al. [20], Rasul et al. [13], and Pooniya et al. [15]. Harvest index is a measure of physiological productivity potential of a crop or variety. It is the ability of a crop to convert the dry matter into economic yield. The higher the harvest index value, the more the production efficiency and vice versa. So the highest harvest index also implies higher partitioning of dry matter into grain. Thus, selection for varieties having high seed to biomass ration such as Mariye could enhance chickpea yield. Overall, the results from this study showed significant variation among the evaluated varieties with respect to studied agronomic characters. This indicated that appreciable variation existed within the Kabuli and Desi type chickpea varieties and could be utilized in breeding programs in the region.

\section{Conclusion}

From the present study, the following conclusions are drawn. There is considerable variation among varieties for the studied agronomic parameters. Earliness plays a crucial role in varieties adaptation to existing and new environments and cropping systems and has a prevailing effect on yield and yield stability. From the result Desi type chickpea variety flowered and matured earlier than Kabuli type chickpea. Based on the present findings, blended fertilizer rates utilized in Tselemti District did not show differences in most of studied traits. Reasonably row spacing of $20 \mathrm{~cm}$ for both types of chickpea could be used for the studied area.

\section{Data Availability}

The data used to support the findings of this study are available from the corresponding author upon request.

\section{Conflicts of Interest}

The authors declare that they have no conflicts of interest.

\section{Acknowledgments}

The research was supported by Tigray Agricultural Research Institute.

\section{References}

[1] A. Fikre, "An overview of chickpea improvement research program in Ethiopia," in Legume Perspective, D. Rubiales, Ed., pp. 47-50, International Legume Society, 2014.

[2] D. K. Kamithi, A. M. Kibe, and T. E. Akuja, "Effects of nitrogen fertilizer and plant population on growth, yield and harvest index (HI) of chickpea (Cicer arietinumL.) under dry land conditions in Kenya," Journal of Applied Biosciences, vol. 22, pp. 1359-1367, 2009.

[3] CSA (Central Statistical Authority), Report on Area and Production of Major Crops (Private Peasant Holdings, Meher Season), FDRE Statistical Bulletin, Addis Ababa, Ethiopia, 2015.

[4] R. Purushothaman, H. D. Upadhyaya, P. M. Gaur, C. L. L. Gowda, and L. Krishnamurthy, "Kabuli and desi chickpeas differ in their requirement for reproductive duration," Field Crops Research, vol. 163, pp. 24-31, 2014.

[5] G. W. Gee and J. W. Bauder, "Particle size analysis," in Methods of Soil Analysis: Part 1-Physical and Mineralogical Methods, A. Klute, Ed., Agronomy Monograph, Agronomy Monograph no. 9, pp. 383-411, American Society of Agronomy, Madison, WI, USA, 2nd edition, 1986.

[6] Dawis and Frietas, Physical and Chemical Methods of Soil Analysis, no. 10, FAO Bulletin, Rome, Italy, 1970.

[7] M. F. Morgan, "Chemical diagnosis by the universal soil tests system," Conn.Agr. exp. Sta (New Haven) Bull, vol. 450, 1941.

[8] J. R. Okalebo, K. W. Guathua, and P. L. Woomer, "Soil laboratory methods and plant analysis," Working Manual, Karhsobf, Nairobi, Kenya, p. 55, 1993.

[9] S. Sahelemedhin and T. Bekele, "Procedures for soil and plant analysis," Technical paper 74, National Soil Research Center, Ethiopia Agricultural Research Organization, Addis Ababa, Ethiopia, 2000.

[10] A. Asrat, Response of chickpea (Cicer arietinum L.) varieties to rates of nitrogen and phosphorus fertilizer rate at Debre Zeit, Central Ethiopia, Haramaya University, 2013.

[11] M. A. Malek, M. Shafiquzzaman, M. S. Rahman, M. R. Ismail, and M. M. A. Mondal, "Standardization of soybean row spacing 
based on morpho-physiological characters," Legume Research, vol. 35, no. 2, pp. 138-143, 2012.

[12] B. Uzun, E. Yol, and S. Furat, "The influence of row and intrarow spacing to seed yield and its components of winter sowing canola in the true Mediterranean type environment," Bulgarian Journal of Agricultural Science, vol. 18, no. 1, pp. 83-91, 2012.

[13] F. Rasul, M. A. Cheema, A. Sattar, M. F. Saleem, and M. A. Wahid, "Evaluating the performance of three mungbean varieties grown under varying inter-row spacing," Journal of Animal and Plant Sciences, vol. 22, no. 4, pp. 1030-1035, 2012.

[14] S. Farjam, M. J. Kenarsari, A. Rokhzadi, and B. Yousefi, "Effects of Inter-row spacing and superabsorbent polymer application on yield and productivity of rainfed chickpea," Journal of Biodiversity and Environmental Sciences, vol. 5, no. 3, pp. 316320, 2014.

[15] B. Pooniya, R. K. Rai, and Jat., "Yield and yield attributes of chickpea (Cicer arietinumL.) as influenced by various row spacing and weed control," Indian Journal of weed science Science, vol. 41, no. 3\&4, pp. 222-223, 2009.

[16] A. Mahmood and B. Honermeier, "Effect of row spacing and cultivar on biomass yield and quality of Sorghum bicolor L. Moench," Journal fur Kulturpflanzen, vol. 64, no. 7, pp. 250-257, 2012.

[17] J. Sarkodie-Addo and O. Mahama, "Growth and yield response of early and medium maturity soybean (Glycine max (L) merrill) varieties to row spacing," International Journal of Science and Advanced Technology, vol. 2, no. 11, 2012.

[18] X. B. Zhou, L. Qi, G. M. Yang, and Y. H. Chen, "Row spacing effect on soil and leaf water status of summer soybean," Journal of Animal and Plant Sciences, vol. 21, no. 4, pp. 680-685, 2011.

[19] R. Raymond, K. McKenzie, and R. C. N. Rachaputi, Impact of row spacing on faba bean yield, Australian Grain, 2015.

[20] A. M. Gezahegn, K. Tesfaye, J. Sharma, M. Belel, and M. Tejada Moral, "Determination of optimum plant density for faba bean (Viciafaba L.) on vertisols at Haramaya, Eastern Ethiopia," Cogent Food \& Agriculture, vol. 2, no. 1, 2016. 


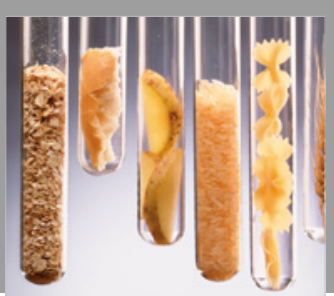

International Journal of Food Science

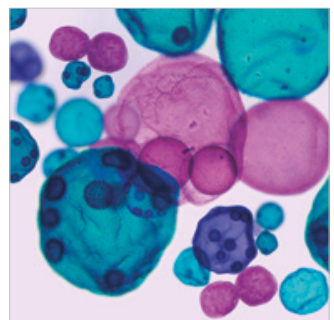

International Journal of Microbiology
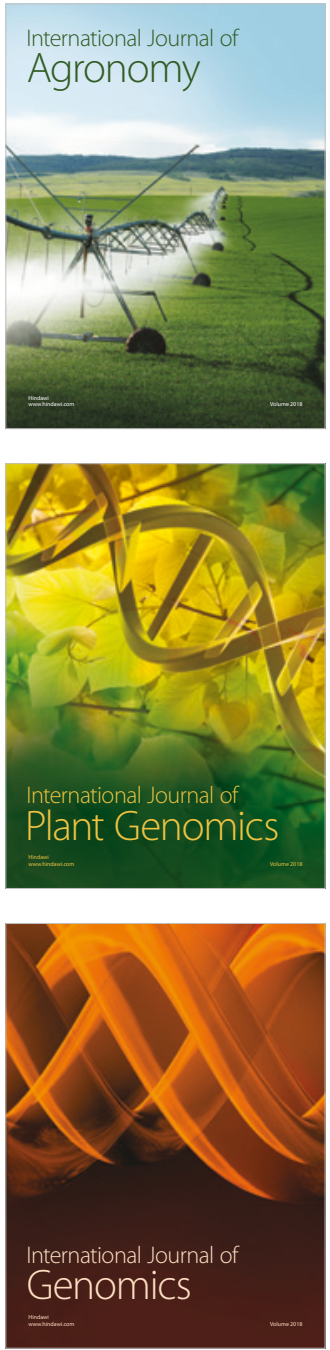

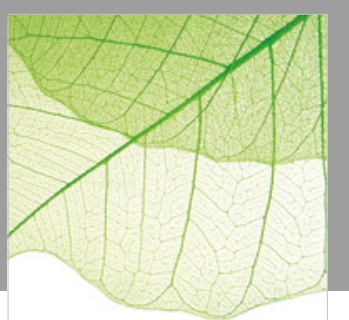

Journal of Botany
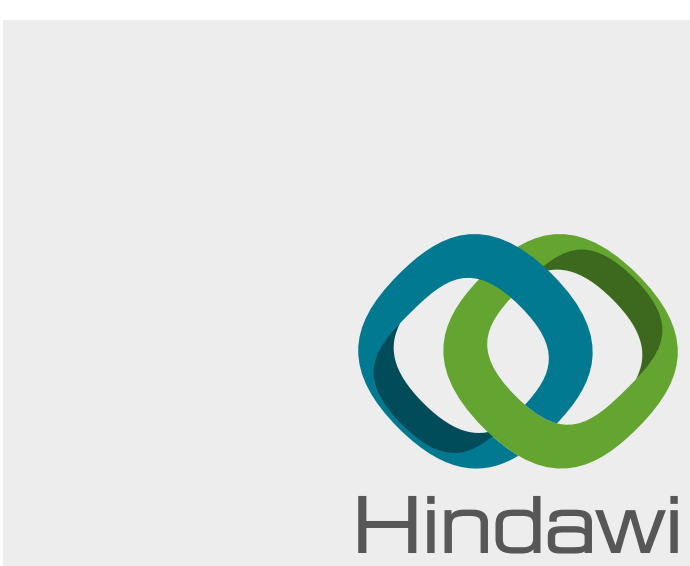

Submit your manuscripts at

www.hindawi.com
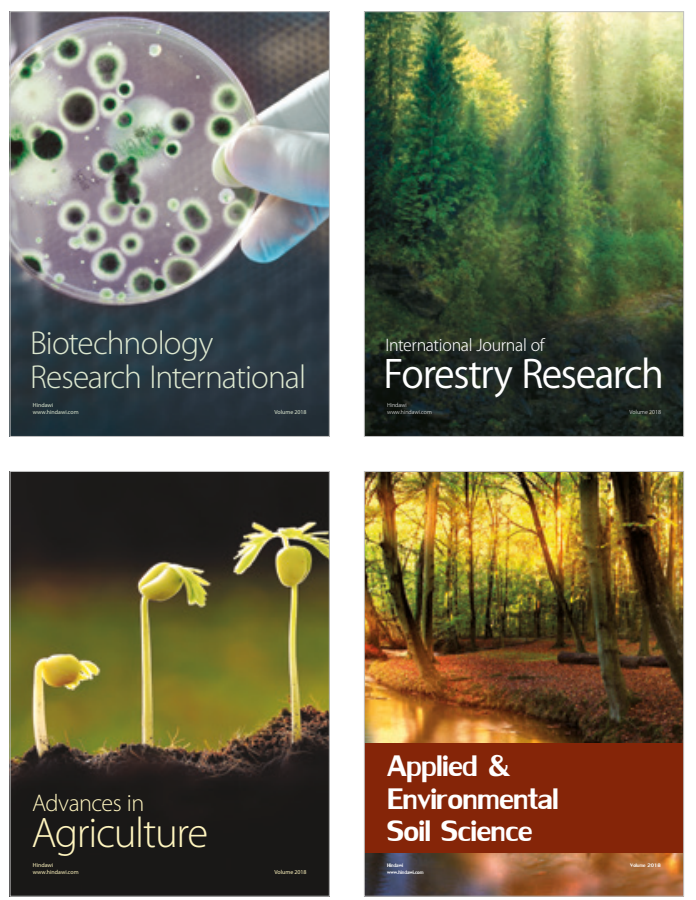

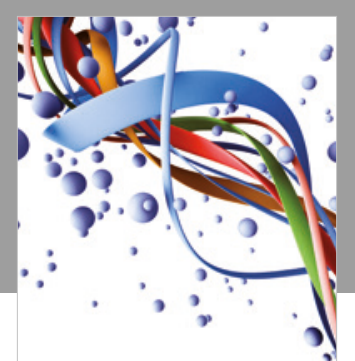

Scientifica

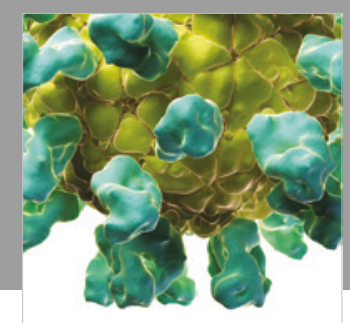

Veterinary Medicine International

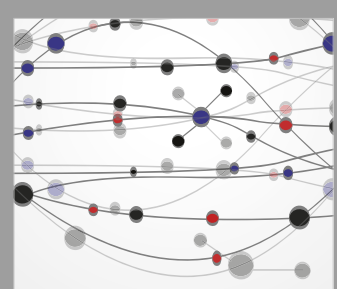

The Scientific World Journal
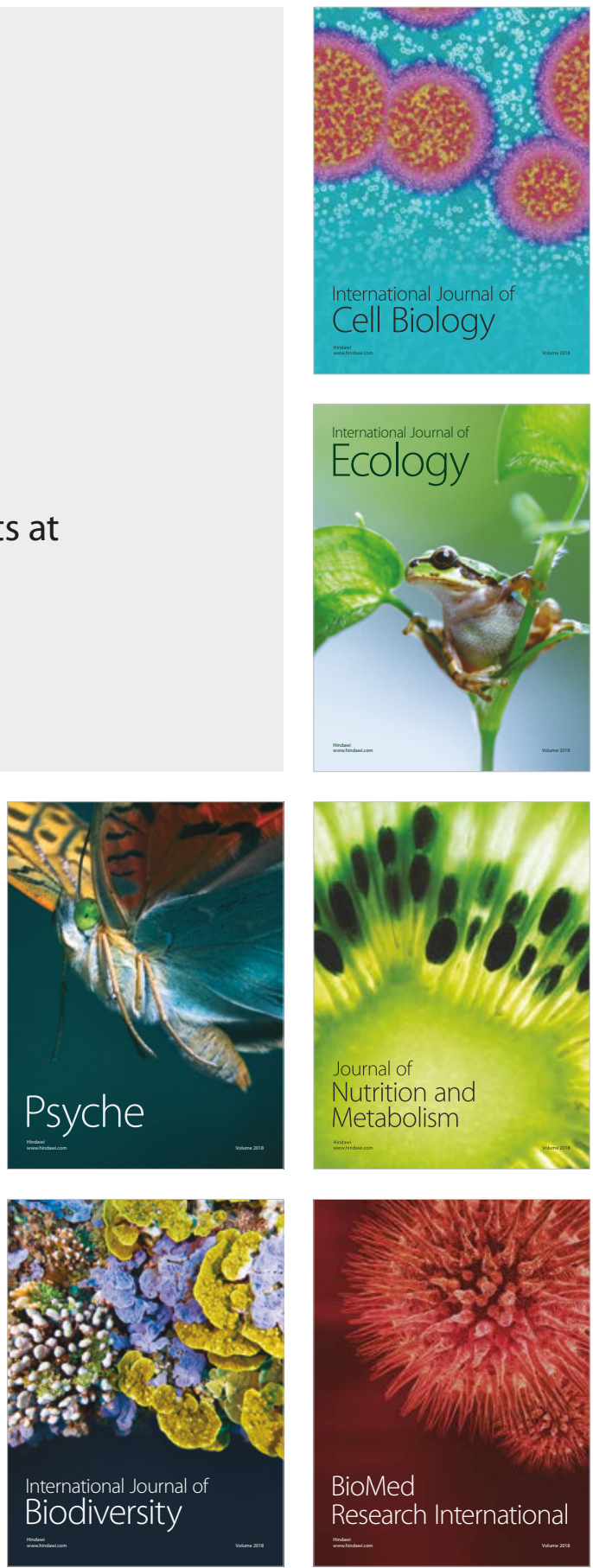